УАK 338.439

Ю. М. Аучечко, аспірант, Ауцький національний технічний університет

DOI: $10.32702 / 2306-6792.2018 .24 .60$

МОАЕРНІЗАЦІЯ ІНАУСТРІЇ ПЕРЕРОБКИ

СІАЬСЬКОГОСПОААРСЬКОЇ СИРОВИНИ ЯК ПРІОРИТЕТНИЙ НАПРЯМ ІНВЕСТИЦІЙНОЇ

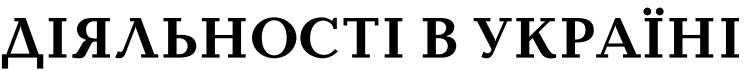

\author{
Yu. Luchechko, \\ Postgraduate student, Lutsk National Technical University
}

\title{
MODERNIZATION OF THE INDUSTRY OF PROCESSING OF AGRICULTURAL RAW MATERIALS AS A PRIORITY TREND OF INVESTMENT ACTIVITY IN UKRAINE
}

Обгрунтовано, що інвестиційна діяльність у національній економіці гальмується через відсутність сприятливого інституціонального середовища нарощення обсягів інвестування суб'єктами господарювання за рахунок внутрішніх Ажерел, низьку інвестиційну привабливість переважної більшості сегментів національного господарства та нерозвиненість інфраструктури національного інвестиційного ринку. Встановлено, що в нинішніх умовах господарювання модернізація індустрії переробки сільськогосподарської сировини виступає пріоритетним напрямом інвестиційної Аіяльності в економіці України в цілому, що пов'язано з нарощенням обсягів виробництва сільськогосподарської продукції в останні роки та зміцненням експортних мождивостей вітчизняних сільськогосподарських виробників. Обгрунтовано, що подолання негативних тенденцій в динаміці індексу росту фізичного капіталу та залучення іноземних інвестицій в економіці України стане можливим за рахунок створення сприятливих інституціональних переАумов Аля інвестиційної Аіяльності в аграрному секторі, який в останні роки став структуроутворюючою галуззю Аля всього господарського комплексу країни. Аоведено, що найбільш привабливою складовою національного АПК Аля нарощення інвестиційних потоків $є$ переробно-харчовий сегмент, який за відповідного рівня модернізації та реконструкції виробничо-технічної бази зАатен на порядок збільшити обсяги виробництва продукції з високою доданою вартістю та переорієнтувати вітчизняний аграрний експорт з сировинної спрямованості на продаж готових харчових продуктів. Встановлено, що значний синергетичний ефект Аля розвитку регіональних агропромислових комплексів зАатний надати інвестиційне забезпечення впровадження на незадіяних майданчиках спиртових заводів виробництв біоетанолу, що дозволить поступово зменшувати залежність країни віА імпорту енергоносіїв та підвищувати рівень комплексності переробки сільськогосподарської сировини.

It is proved that investment activity in the national economy is hampered by the lack of a favourable institutional environment to increase the volume of investment by economic entities at the expense of domestic sources, low investment attractiveness of the vast majority of segments of the national economy and underdeveloped infrastructure of the national investment market. It is established that in the current economic conditions the modernization of the industry of processing of agricultural raw materials is a priority area of investment in the economy of Ukraine as a whole, which is associated with the increase in agricultural production in recent years and the strengthening of export opportunities of domestic agricultural producers. It is proved that overcoming the negative trends in the dynamics of the growth index of physical capital and attracting foreign investment in the economy of Ukraine will be possible through the creation of favourable institutional conditions for investment in the agricultural sector, which in recent years has become a structuring industry for the entire economic complex of the country. It is proved that the most attractive part of the national agro-industrial complex for increasing investment flows is the food-processing segment, which for the appropriate level of modernization and reconstruction of the production and technical base is able to increase the volume of production with high added value and reorient domestic agricultural exports from raw materials to the sale of finished food products. It is established that a significant synergetic effect for the development of regional agro-industrial complexes is able to provide investment support for the introduction of bioethanol production at idle sites of alcohol plants, which will gradually reduce the country's dependence on energy imports and increase the level of complexity of processing of agricultural raw materials.

Ключові слова: модернізачія, переробка сільськогосподарської сировини, інвестичійна діяльність, фізичний капітал, іноземні інвестичї, основний капітал.

Keywords: modernization, processing of agricultural raw materials, investment activity, physical capital, foreign investments, fixed capital.

\section{ПОСТАНОВКА ПРОБЛЕМИ У ЗАГАЛЬНОМУ ВИГЛЯДІ ТА ІІЇ ЗВ'ЯЗОК ІЗ ВАЖЛИВИМИ НАУКОВИМИ ЧИ ПРАКТИЧНИМИ ЗАВДАННЯМИ}

Прискорення темпів соціально-економічного піднесення в Україні значною мірою зале- жить від активізації інвестиційної діяльності в національному господарстві. В останні роки внаслідок загострення комплексу ендогенних та екзогенних ризиків не відбувається позитивних проривних змін в частині нарощення інвестиційних потоків як за рахунок внутрішніх дже- 
рел суб'єктів господарювання, коштів акумульованих на ринку позикового капіталу, а також фінансових ресурсів іноземних підприємницьких структур. Переломлення такої негативної тенденції напряму пов'язане зі створенням сприятливих інституціональних передумов здійснення інвестиційної діяльності в секторах господарського комплексу, де мають місце надзвичайно сприятливі передумови для збільшення обсягів виробництва продукції 3 високою доданою вартістю. Таким сектором виступає переробно-харчова промисловість, котра при збільшенні обсягів інвестування процесів модернізації та реконструкції основного капіталу здатна на порядок збільшити виробництво конкурентноспроможної продукції і відродити суміжні з нею галузі, що в підсумку забезпечить реальні зрушення в соціально-економічному розвитку регіонів аграрної спеціалізації. Тобто нині модернізацію індустрії переробки сільськогосподарської сировини варто розглядати як один з основних пріоритетів активізації інвестиційної діяльності з огляду на наявні позитивні тренди в аграрному секторі національної економіки та глобальні виклики в частині забезпечення населення світу продовольством, а також потенційні можливості зменшення енергозалежності країни за рахунок виробництва твердого, рідкого та газоподібного біологічного палива на основі переробки відходів сільськогосподарського виробництва.

\section{АНАЛІЗ ОСТАННІХ ДОСЛІДЖЕНЬ І ПУБЛІКАЦІЙ}

Питання активізації інвестиційної діяльності у переробно-харчовому сегменті національного АПК вже тривалий період розглядаються у працях вітчизняних вчених таких як А. Бритвєнко, В. Страшинський, О. Тарасова, Ю. Тінтулов, Т.Товста та інших. Увага акцентується на ролі харчової промисловості в покращенні інвестиційного клімату в країні в цілому [1], на проблемах підвищення інвестиційної привабливості переробно-харчових виробництв [4], виявленні чинників залучення іноземних інвестицій в переробну ланку АПК [7], формуванні системи організаційно-правових та фінансово-економічних інструментів регулювання інвестиційного процесу у сфері переробки сільськогосподарської сировини [6], обгрунтуванні найбільш ефективних напрямів капіталовкладень в харчовій промисловості [5].

Виходячи 3 останніх трендів на світових ринках продовольства та динаміки розвитку вітчизняного аграрного сектора ряд вчених однозначно розглядають харчову промис- ловість як пріоритетний напрям інвестиційної діяльності в Україні. Зокрема А. Бритвєнко стверджує, що харчова промисловість найбільш інвестиційно приваблива галузь української промисловості, що характеризується швидкою окупністю інвестицій, базою сировини для виробництва харчової продукції та існуванням ринків збуту. Сфера харчової промисловості характеризується меншою залежністю від кон'юнктурних змін на зовнішніх ринках завдяки значній ємності внутрішнього ринку та низькій еластичності попиту на продовольчу продукцію, тому надходження інвестицій, зокрема на підприємства харчової промисловості, дасть змогу покращити інвестиційний клімат України [1]. Незважаючи на однозначність думок стосовно пріоритетності нарощення інвестиційних потоків у переробнохарчовий сегмент АПК, вирішення цього завдання є доволі ускладненим, оскільки залучення інвестицій у продовольчий комплекс, як вважають О. Тарасова та М. Міхов, будучи складним і багатоаспектним народногосподарським завданням, охоплює цілий комплекс організаційно-правових та фінансово-економічних питань регулювання, спрямованих на формування діючих механізмів залучення інвестицій у харчову промисловість і пов'язаних 3 нею галузей [5]. Саме формування набору організаційно-правових та фінансово-економічних важелів регулювання інвестиційних процесів у переробно-харчових галузях потребує внесення змін у нормативно-правове поле та численні підзаконні акти, що вимагає концентрації зусиль на різних рівнях системи державного управління.

Надзвичайно важливим при цьому є умонтування в комплекс перерахованих важелів регулювання інвестування в переробній ланці агропродуктового ланцюга стимулюючих залучення інвестицій підойм. 3 цього приводу окремі вчені акцентують увагу на факторах, які стимулюють інвестиційну діяльність в переробному сегменті АПК. Факторами, що стимулювали інвестиційну діяльність в харчовій промисловості в період економічної стабільності, на думку Т. Товстої, були: зростання обсягу валового внутрішнього продукту, підвищення доходів населення, зміцнення платіжно-розрахункової дисципліни, покращення фінансового стану підприємств харчової промисловості [7].

Т. Товста також переконана, що через низьку інвестиційну активність іноземних компаній, нерівномірний регіональний розподіл інвестиційних надходжень і високий рівень потреби 
економіки у залученні капіталу особливої актуальності набуває питання визначення пріоритетів інвестиційної діяльності, вибору її найефективніших напрямів на рівні окремих підприємств, що потребує відповідної інформації про інвестиційну привабливість харчової промисловості та обгрунтування методичних основ $\dddot{11}$ визначення [7].

На необхідності створення умов для покращення інвестиційної привабливості переробно-харчового сегмента АПК акцентує увагу також В. Страшинський, який вважає, що зважаючи на економічні та політичні труднощі, які негативно впливають на агропромисловий сектор, більшої уваги потребує проблема залучення іноземних інвестицій та підвищення інвестиційної привабливості як країни в цілому, так і галузей харчової промисловості, вирішенню якої сприятиме система ефективного державного регулювання інвестиційних процесів [4]. Тобто перспективи нарощення інвестиційних потоків у переробнохарчові виробництва національного АПК прив'язуються до проблеми підвищення рівня інвестиційної привабливості даного сектора економіки, що потребує застосування комплексу заходів стосовно надання необхідної інформації потенційним інвесторам та покращення умов для приходу у вітчизняний переробний сегмент агропромислової сфери іноземних інвесторів.

\section{META CTATTI}

Метою публікації $є$ виявлення основних тенденцій залучення інвестиційних потоків в національну економіку та обгрунтування шляхів нарощення інвестицій в модернізацію індустрії переробки сільськогосподарської сировини як структуроутворюючу галузь господарського комплексу та пріоритетний напрям інвестиційної діяльності в Україні в ціломy.

\section{ВИКЛАД ОСНОВНОГО МАТЕРІАЛУ ДОСЛІДЖЕННЯ}

Інвестиційна діяльність в Україні великою мірою визначалася і визначається рівнем економічної стабільності, темпами зростання ВВП та рівнем інвестиційної привабливості окремих сегментів для іноземного капіталу. Значним поштовхом щодо нарощення інвестиційних потоків в національну економіку стала макроекономічна стабілізація, яка розпочалася у 2000 році та тривала до 2008 року до початку глобальної фінансової кризи. Саме в цей період і відбулося становлення вітчизняного інвестиційного ринку на основі поєднання рудиментів централізованого фінансування капітальних вкладень, які мали місце в умовах командно-адміністративної економіки (для підприємств державної форми власності), та впровадження сучасних ринкових форм інвестування процесів модернізації, реконструкції, технічного переоснащення та нового будівництва окремих складових основного капіталу.

Починаючи з 2001 року і дотепер в Україні спостерігається активне зростання номінального обсягу капітальних інвестиції, що здійснюються підприємствами та організаціями. Виключеннями стали лише 2009 та 2014 роки, протягом котрих мало місце загострення геоекономічних та геополітичних ризиків, зумовлених відповідно глобальною економічною кризою та початком конфлікту на сході країни. В цілому, за період що аналізується, сума капіталовкладень в національну економіку зросла в 13 разів - 32,6 у 2001 році до 448,6 млрд грн у 2017 році (рис. $1)$.

Разом із тим, у ринковій економіці відбувається перманентне зростання цін і кількість обладнання та техніки, що можна запустити у виробничий оборот за одну і ту саму суму фінансових ресурсів, у різні періоди коливається. Аля цього вводиться індекс фізичного капіталу в Україні, що показує збільшення реального капіталу та відображає динаміку умовної фізичної кількості одиниць обладнання та устаткування незалежно від збільшення індексу цін виробників та дефлятора ВВП. Так, найбільше одиниць обладнання та устаткування було введено протягом 2001-2008 років (період макроекономічної стабілізаціі). Тоді, як у 2017 році значення індексу росту фізичного капіталу виявилось на рівня 2003 року 122,6 в.п.

Якщо аналізувати участь іноземного капіталу у національній економіці, зокрема надходження прямих іноземних інвестицій у 20012018 роках, то спостерігається така картина: прямі іноземні інвестиції у гривневому еквіваленті починаючи з 2001 року і завершуючи початком 2018 року в цілому демонструють висхідну тенденцію (рис. 2).

Така ж сама картина спостерігалася й в динаміці прямих іноземних інвестицій в доларовому вираженні, але лише до 2014 року. Після 2014 року величина прямих іноземних інвестицій (акціонерного капіталу) в Україні в доларовому еквіваленті знизилася. Якщо у 2014 році сума прямих іноземних інвестицій в еко- 


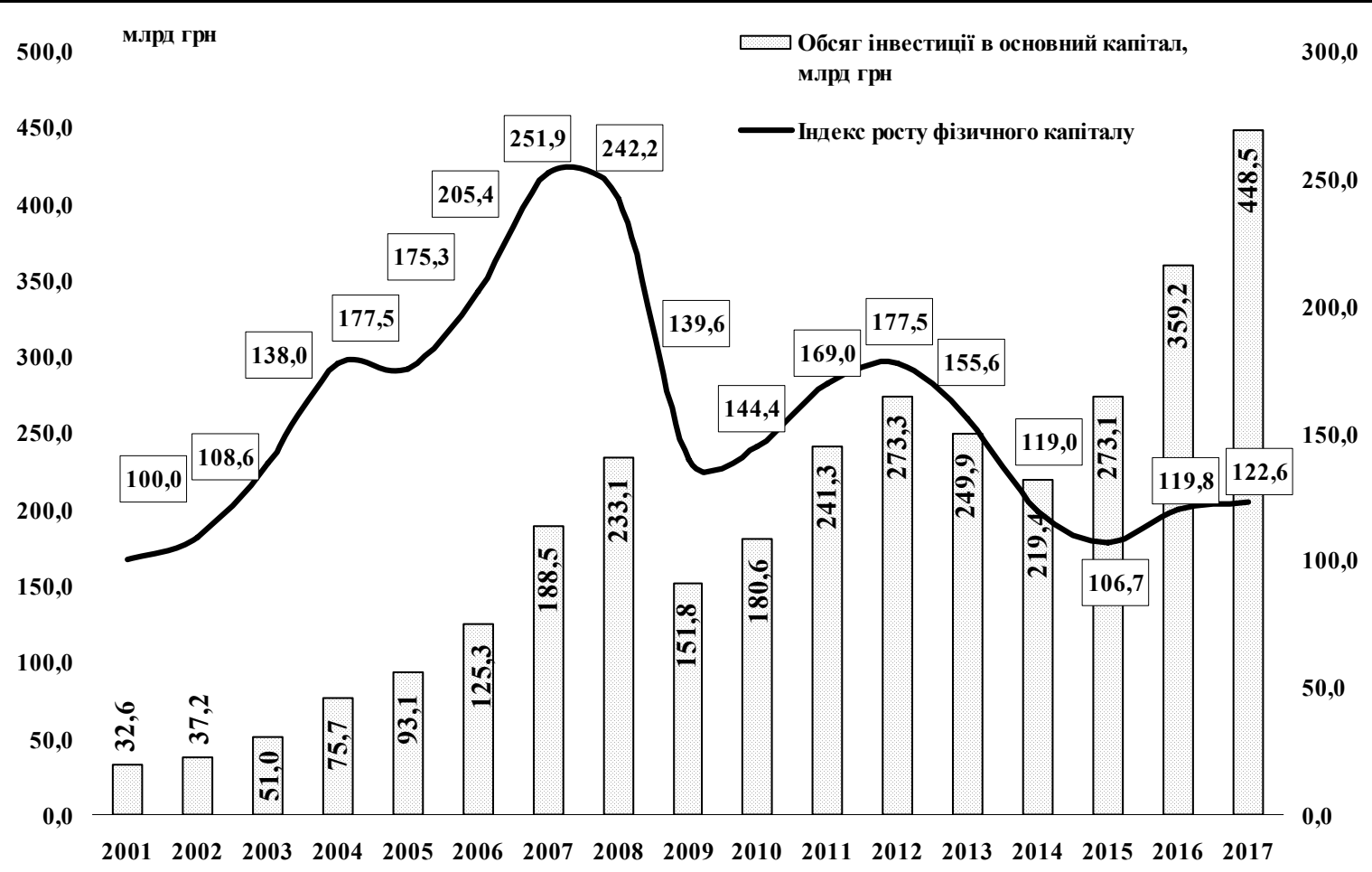

Рис. 1. Динаміка індексу росту фізичного капіталу в Україні протягом 2001-2017 років, $2001=100$

Ажерело: розраховано за даними Аержавної служби статистики України та НБУ.

номіці України становила 53,7 млрд дол., то на початок 2018 року - 39,1 млрд дол. Фактично за 3 останні роки іноземні інвестори вивели 3 України більше 14 млрд дол. інвестиційного капіталу.

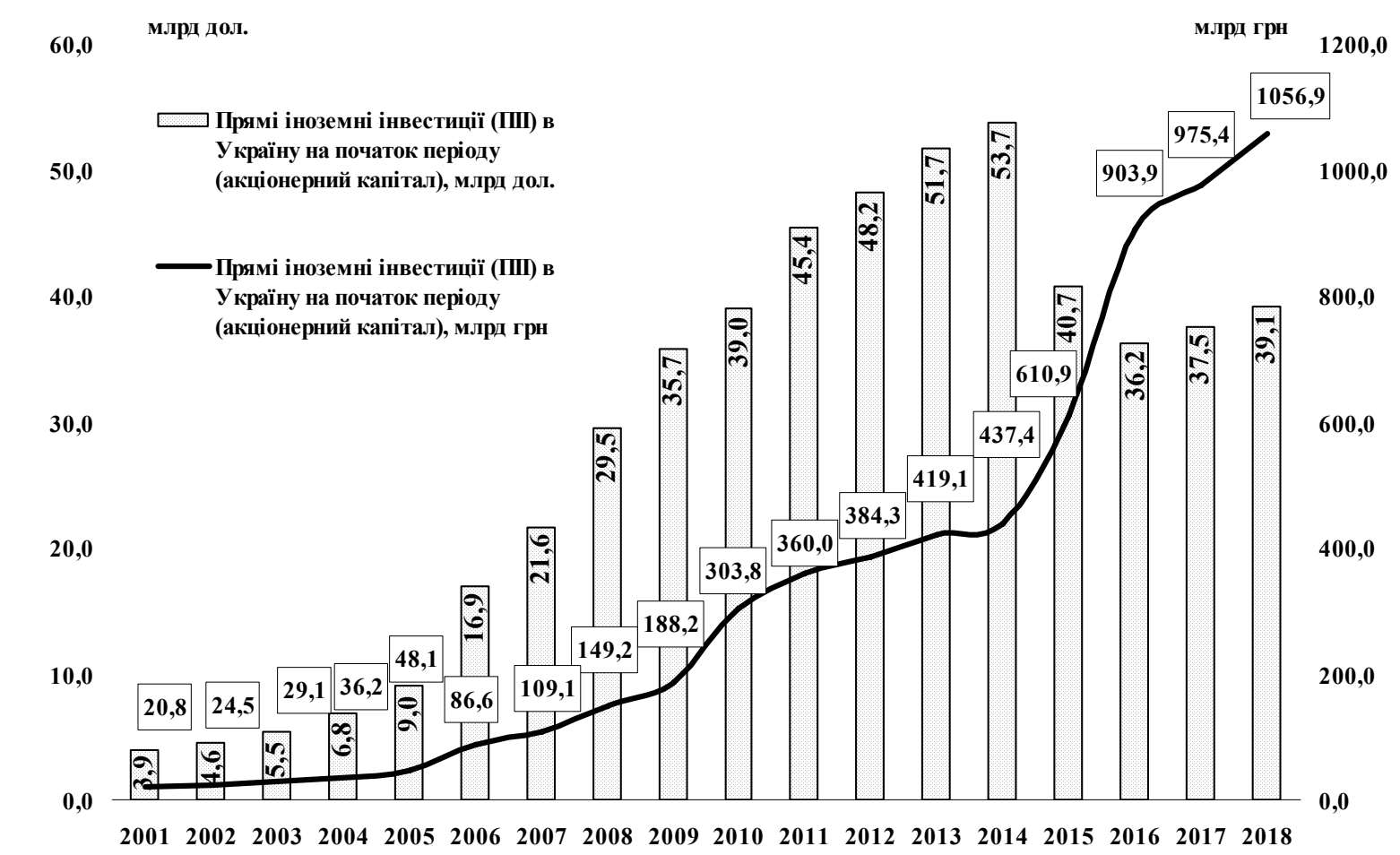

Рис. 2. Прямі іноземні інвестиції в доларовому та гривневому еквіваленті

Ажерело: розраховано за даними Аержавної служби статистики України та НБУ.
Зростання прямих іноземних інвестицій (акціонерного капіталу) в економіці України у гривневому еквіваленті у 2014-2018 роках було забезпечене надмірними темпами інфляційно-девальваційних коливань, навіть незва- 
жаючи на реальний відтік іноземних інвестицій 3 національної економіки.

Збереження в цілому сировинної спрямованості національно ̈̈ економіки, а також відсутність позитивних зрушень стосовно модернізації і реконструкції високотехнологічних виробництв не забезпечать у короткостроковій перспективі суттєвого нарощення іноземних інвестицій, що не дасть можливості зменшити енерго- та ресурсомісткість промислового виробництва і тим самим підвищити рівень конкурентоспроможності вітчизняної продукції як на світовому, так і на національному ринку [3].

Суттєве підвищення рівня конкурентоспроможності продукції українських товаровиробників як на вітчизняному, так і на закордонному ринках стане можливим за умови нарощення інвестиційних потоків в модернізацію та реконструкцію основного капіталу. Однак економічна стагнація 90-х років минулого століття та посткризового періоду 2009-2018 років звузила інвестиційні можливості суб'єктів господарювання більшості галузей національного господарства. Тим більше, що в останні роки відбулися зміни в структурі національної економіки, які призвели до посилення ролі аграрного сектора в системі суспільного відтворення, що супроводжується збільшенням частки агропромислового виробництва в структурі загальної доданої вартості та зростанням частки сільськогосподарської та харчової продукції в структурі українського експорту. Саме ці фактори, а також сприятливі природно-ресурсні передумови розвитку рослинницької та тваринницької галузей перетворили аграрний сектор у "локомотив" розвитку всього господарського комплексу, в тому числі і стосовно перспектив нарощення обсягів інвестиційного забезпечення проектів модернізації та реконструкції переробки сільськогосподарської сировини. Саме розбудова вітчизняної індустрії переробки сільськогосподарської сировини дасть можливість зменшити сировинні потоки в аграрному експорті і збільшити обсяги продукції з високою доданою вартістю, що сприятиме підвищенню рівня капіталізації переробних сегментів агропродуктового ланцюга і відповідно зростатиме ефективність виробничо-господарської діяльності суміжних галузей.

Мова йде про переробно-харчову індустрію, яка охоплює харчову промисловість та виробництва по переробці сільськогосподарської сировини в цілях, не пов'язаних з виробництвом харчових продуктів. Харчова промисловість завжди вважалася для України пріори- тетною і стратегічно важливою галуззю, яка здатна задовольнити не тільки потреби внутрішнього ринку, а й забезпечити провідне місце держави серед лідерів із виробництва якісного продовольства. Біокліматичні умови нашої країни дають можливість збільшувати обсяги виробництва та забезпечувати населення якісною харчовою продукцією, тому стратегічним завданням цієї галузі є експорт. Крім того, потенціал вітчизняного сільського господарства, що забезпечує харчову промисловість сировиною, дозволяє вивести нашу країну на достатній рівень продовольчого самозабезпечення та налагодити експорт, водночас утримуючи лідируючі позиції в міжнародній торгівлі продовольством [4]. Ао чинників, які реально можуть впливати на активізацію залучення іноземних інвестицій в харчову промисловість України, відносяться: стабілізація правового поля держави (законодавчої бази); інтеграція політичної волі усіх гілок влади; нормалізація стану фінансово-кредитної системи; підвищення пріоритетності статусу іноземного інвестора; підвищення інвестиційної активності населення [7].

В останній час все більшої вагомості набуває такий сегмент індустрії переробки сільськогосподарської сировини як виробництво різних видів палива з відходів рослинництва та тваринництва. Зрештою такі виробництва мають стати ефективним доповненням основних виробництв підприємств харчової промисловості, де утворюються значні обсяги відходів.

Також значний поштовх розвитку переробного сегмента національного АПК надасть модернізація індустрії переробки вториннӧ̈ сільськогосподарської сировини як рослинного, так і тваринного походження, що сприятиме збільшенню обсягів виробництва біологічного палива і поступовому зменшенню тим самим залежності від зовнішніх джерел постачання енергоносіїв та нарощенню обсягів виробництва цінних кормових добавок. Це є перспективним з огляду на те, що реконструкція й технічне переоснащення виробництва - найбільш ефективні напрямки капіталовкладень у харчовій промисловості. Це дає змогу в коротші строки, з меншими витратами, ніж при новому будівництві, оновлювати матеріально-технічну базу, освоювати нові потужності. Це також дозволить збільшувати частку витрат на устаткування, тобто на активну частину основних фондів [5].

Показовим прикладом в цьому плані при створенні відповідних інституціональних умов може стати інвестиційна діяльність підпри- 
ємств спиртової промисловості як в частині відновлення виробництва спирту та супутніх видів продукції, так і перепрофілювання незадіяних виробничих майданчиків на виробництво біоетанолу. Це насамперед налагодження виробництва біоетанолу та альтернативного моторного палива з його вмістом на незадіяних виробничих майданчиках спиртових підприємств. Налагодження виробництва біоетанолу дасть змогу забезпечувати використання в моторному паливі екологічно чистого компоненту, який суттєво знижує викиди токсичних речовин, зменшує залежність від імпорту енергоносіїв, покращує загальну екологічну ситуацію в країні.

Тим більше, що нарощення виробництва біоетанолу вимагається Національним планом дій 3 відновлюваної енергетики на період до 2020 року, згідно з яким загальний очікуваний внесок біоетанолу, етилтретбутилового ефіру, виробленого з біоетанолу, для досягнення обов'язкових індикативних цілей щодо їх споживання на транспорті на 2020 рік заплановано в обсязі 320 тис. тонн нафтового еквіваленту. А обсяги виробництва проАукції на основі етанолу (біоетанолу) у 2017 році, за експертними оцінками, становили всього 80-85 тис. тонн. За такого обсягу $\mathrm{У}_{\mathrm{K}-}$ раїна не зможе виконати вимоги ЕС щодо обов'язкового використання $10 \%$ біопалива або іншого відновлюваного ресурсу в пальному для транспорту.

Вагомим чинником підвищення інвестиційної привабливості підприємств спиртової промисловості є те, що місця провадження діяльності (МПА), на яких планується організація виробництва біоетанолу та палива моторного альтернативного, знаходяться в регіонах, де $\epsilon$ достатній обсяг цукровмісної та крохмалевмісної сировини. На сьогодні ця сировина експортується в країни, де з неї виготовляють біоетанол. Тобто фактично вивозиться додана вартість, яка за допомогою незадіяних сьогодні потужностей може створюватися в Україні й давати синергетичний ефект як для сільськогосподарських товаровиробників, так і для переробно-харчових виробництв [8]. Налагодження виробництва біоетанолу на МПА у Вінницькій, Київській, Аьвівській, Тернопільській, Черкаській та Чернівецькій областях сприятиме отриманню переробно-харчовим сегментом АПК цих регіонів нових імпульсів для розвитку як в частині диверсифікації виробництва, так і в частині нарощення інвестиційних потоків в модернізацію активної частини основного капіталу, що поступово виведе зі стану стагнації й суміжні із спиртовим виробництвом галузі.

Каталізатором пожвавлення інвестиційної активності підприємств спиртової промисловості стало прийняття законопроекту № 9260 "Про внесення змін до Податкового кодексу та деяких інших законодавчих актів щодо покращення адміністрування та перегляду ставок окремих податків і зборів", яким передбачено оподаткування технічного спирту за нульовою ставкою: спирту етилового денатурованого, який використовується для виробництва проАукції хімічного і технічного призначення; спирту етилового неденатурованого, який використовується для виробництва оцту з харчової сировини; спирту етилового денатурованого, що використовується для виробництва парфумерно-косметичної продукції; спирту етилового-сирцю, що використовується в межах одного суб'єкта господарювання для виробництва біоетанолу; спирту етилового, що переміщується між акцизними складами в межах одного суб'єкта господарювання [2]. Цей законодавчий акт знижує фіскальне навантаження на виробників технічного спирту і тим самим створює умови для підвищення рівня капіталізації і відповідно нарощення внутрішніх джерел інвестування проектів модернізації, реконструкції та технічного переоснащення основних засобів.

\section{ВИСНОВКИ I ПЕРСПЕКТИВИ ПОДАЛЬШИХ РОЗВІДОК}

Приріст інвестиційних вливань у господарському комплексі як за рахунок внутрішніх, так і зовнішніх джерел залежить від удосконалення інституціонального середовища функціонування інвестиційного ринку та створення умов для нарощення інвестиційних потоків у модернізацію та реконструкцію основного капіталу в галузях, де спостерігається високий рівень концентрації інвестиційного капіталу. Виходячи 3 нинішньої відтворювальної структури національної економіки, зрушень у структурі ВВП та структури експортних поставок, пріоритетним напрямом інвестиційної діяльності слід вважати модернізацію індустрії переробки сільськогосподарської сировини 3 огляду на позитивну динаміку обсягів виробництва в сировинному сегменті АПК та перспективи виходу на зовнішні ринки з продукцією 3 високою доданою вартістю. Одним 3 основних пріоритетів активізації інвестиційної діяльності в переробно-харчовому секторі АПК є налагодження виробництва біоетанолу на незадіяних майданчиках спиртових виробництв, 
що сприятиме підвищенню рівня капіталізації названих суб'єктів господарювання та дасть змогу підвищити рівень комплексності переробки сільськогосподарської сировини і зміцнити енергетичну незалежність України.

\section{$\Lambda$ ітература:}

1. Бритвєнко А.С. Інвестиційна політика підприємств у сфері харчової промисловості. Вісник Бердянського університету менеджменту та бізнесу. - 2015. - № 1 (29). - C. 27-29.

2. Верховна Рада ухвалила законопроект щодо зниження податку на технічний спирт. URL: https://agravery.com/uk/posts/show/verhovna-rada-uhvalila-zakonoproekt-sodo-znizenna-podatku-na-tehnicnij-spirt

3. Голян В.А. Чому інвестори виводять активи з України. URL:https://lb.ua/blog/vasiliy_golyan/413632 chomu investori vivodyat aktivi_z.html

4. Страшинський B.I. Інвестиційне забезпечення підприємств харчової промисловості: стан, тенденції та проблеми. Науковий часопис НПУ імені М.П. Арагоманова. Серія 18: Економіка і право. - 2015. - Вип. 28. - С. 65-72.

5. Тарасова О.В., Міхов М.М. Проблеми поліпшення інвестиційного клімату в харчовій промисловості України. Економіка харчової промисловості. - 2011. - № 4. - С. 33-36.

6. Тінтулов Ю.В. Залучення інвестицій у розвиток підприємств харчової промисловості. Аграрний вісник Причорномор'я. Економічні науки. - 2013. - № 69. - С. 99-107.

7. Товста Т.А. Інвестиційний фактор розвитку харчової промисловості України. Інвестиції: практика та досвід. - 2009. - № 2. С. $18-20$.

8. Юрій Аучечко: Вихід на європейський ринок біоетанолу прискорить модернізацію спиртової галузі. Економіст. - 2018. - № 9. - C. 2-6.

\section{References:}

1. Brytvyenko, A.S. (2015), "Investment policy of enterprises in the food industry", Visnyk Berdyans'koho universytetu menedzhmentu ta biznesu, vol. 1 (29), pp. 27-29.

2. Agravery (2018), "The Verkhovna Rada has adopted a bill to reduce the tax on technical alcohol", available at: https://agravery.com/uk/ posts/show/verhovna-rada-uhvalilazakonoproekt-sodo-znizenna-podatku-natehnicnij-spirt (Accessed 01 Dec 2018).

3. Holyan, V.A. (2018), "Why investors are withdrawing assets from Ukraine", available at: https://lb.ua/blog/vasiliy_golyan/413632_- chomu investori vivodyat aktivi z.html (Accessed 01 Dec 201̄8).

4. Strashyns'kyy, V.I. (2015), "Investment support for food industry enterprises: state, trends and problems", Naukovyy chasopys NPU imeni M.P.Drahomanova, Seriya 18: Ekonomika i parvo, vol. 28, pp. 65-72.

5. Tarasova, O.V. and Mikhov, M.M. (2011), "Problems of improving the investment climate in the food industry of Ukraine", Ekonomika kharchovoyi promyslovosti, vol. 4, pp. 33-36.

6. Tintulov, Yu.V. (2013), "Attraction of investments in the development of enterprises of the food industry", Ahrarnyy visnyk Prychornomorya, Ekonomichni nauky, vol. 69, pp. 99-107.

7. Tovsta, T.L. (2009), "Investment factor of food industry development in Ukraine", Investytsiyi: praktyka ta dosvid, vol. 2, pp. 18-20.

8. Luchechko, Yu. (2018), "Entrance to the European bioethanol market will accelerate the modernization of the alcohol industry", Ekonomist, vol. 9, pp. 2-6.

Стаття надійшла до редакиї̈ 04.12.2018 p.

\section{Науково-практичний журнал «ЕКОНОМІКА ТА ДЕРЖАВА»}

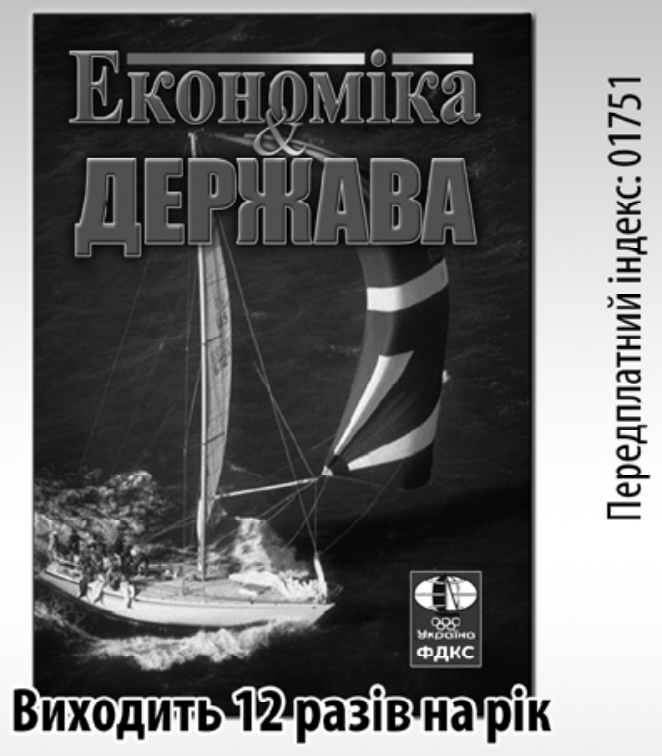

Журнал включено до переліку наукових фахових видань України з ЕКОНОМІКИ

www. economy.in.ua e-mail:economy_2008@ukr.net тел.: (044) 223-26-28 (044) $458-10-73$ 